\title{
Effect of temperature and salinity on in vitro zoosporulation of Perkinsus sp. in Manila clams Ruditapes philippinarum
}

\author{
Kyoung Jin Ahn, Ki Hong Kim* \\ Department of Aquatic Life Medicine, College of Fisheries Science, Pukyong National University, Pusan 608-737, Korea
}

\begin{abstract}
The effects of temperature and salinity on in vitro development of Perkinsus sp. prezoosporangia isolated from cultured Manila clams in Korea were investigated, and the difference in resistance to low temperature between prezoosporangia collected in winter and those collected in summer was compared. Temperature and salinity had significant effects on the development of prezoosporangia, and the developmental rates increased with increasing temperature and salinity. Prezoosporangia isolated in winter sporulated and released motile zoospores at $10^{\circ} \mathrm{C}$, although the rates were significantly lower than those at 20 and $30^{\circ} \mathrm{C}$. However, no prezoosporangia collected in summer sporulated at $10^{\circ} \mathrm{C}$. Low salinities $(\leq 10 \%$ ) had a significant negative effect on the development of prezoosporangia. A small number of prezoosporangia sampled in summer did sporulate at $5 \%$, but further developments including formation and release of zoospores were not observed. However, prezoosporangia sampled in winter and incubated at $5 \%$ released motile zoospores, although the rates were significantly lower than those at higher salinities.
\end{abstract}

KEY WORDS: Perkinsus sp. $\cdot$ Ruditapes philippinarum · Manila clam • Prezoosporangia development · Temperature $\cdot$ Salinity

Resale or republication not permitted without written consent of the publisher

\section{INTRODUCTION}

Perkinsus species are parasites of shellfish, affinities having been suggested both with the Apicomplexa (Perkins 1996) and with the dinoflagellates (Perkins 1996, Siddall et al. 1997). The species have been associated with mass mortalities of commercially important molluscs (Andrews \& Hewatt 1957, da Ros \& Canzonier 1985, Goggin \& Lester 1987). Six species of this genus - P. marinus, $P$. olseni, $P$. atlanticus, $P$. qugwadi (insertae sedis), $P$. chesapeaki and $P$. andrewsi-have been described in molluscs from various parts of the world (Mackin et al. 1950, Lester \& Davis 1981, Azevedo 1989, Blackbourn et al. 1998, McLaughlin et al. 2000, Coss et al. 2001). Recently, unidentified Perkinsus sp. infections in Manila clams Ruditapes

*Corresponding author. E-mail: khkim@pknu.ac.kr philippinarum were reported from Korea, and were considered to be a cause of recent mass mortalities of cultured Manila clams (Choi \& Park 1997, Choi et al. 1998, Park et al. 1999).

Effects of natural environmental factors on the epizootiology of the disease caused by Perkinsus sp., especially $P$. marinus, have been extensively studied, and it is concluded that temperature and salinity are the 2 most important controlling factors (Mackin et al. 1950, Ray 1954, Andrews 1955, Crosby \& Roberts 1990, Chu \& La Peyre 1993, Chu et al. 1993, Ragone Calvo \& Burreson 1994). A few studies have been done on the effects of temperature and salinity on in vitro development of prezoosporangia (Perkins 1966, Chu \& Greene 1989) and cultured cells (Burreson et al. 1994) of $P$. marinus, and prezoosporangia of $P$. atlanticus (Auzoux-Bordenave et al. 1995). Goggin et al. (1990) reported that prezoosporangia and trophozoites of Perkinsus spp. showed high tolerance to a range of 
temperatures, salinities and chlorine concentrations. There are no data, however, concerning differences in tolerance of prezoosporangia to temperature and salinity as a function of the seasons at which the cells were sampled.

In this study, therefore, the effects of temperature and salinity on in vitro development of Perkinsus sp. prezoosporangia isolated from cultured Manila clams in Korea were investigated, and the difference in tolerance to low temperatures between prezoosporangia collected in winter and in summer was compared.

\section{MATERIALS AND METHODS}

Clams. Manila clams Ruditapes philippinarum were collected from cultured clam beds in an inner bay of the southern part of Korea in February and July 2000. The temperature and salinity in February were $9.8^{\circ} \mathrm{C}$ and $32.8 \%$, and in July were $25.0^{\circ} \mathrm{C}$ and $32.3 \%$, respectively. The experiments were conducted immediately after transferring the clams to the laboratory. The same experimental regimen was applied to both winter and summer samples.

Preparation of prezoosporangia. Whole tissues of clams were incubated in fluid thioglycollate medium (FTM; Sigma) for $5 \mathrm{~d}$ in the dark at $30^{\circ} \mathrm{C}$. After incubation, the tissues were minced and washed by centrifugation 4 times in sterile artificial seawater (ASW) adjusted to $30 \%$ and containing 200 units $\mathrm{ml}^{-1}$ penicillin/streptomycin (Sigma) and 500 units $\mathrm{ml}^{-1}$ nystatin (Sigma). The pellet was resuspended in ASW and filtered serially with sterilized gauze. Prezoosporangia were isolated from the filtrate with micropipettes under a stereomicroscope and inoculated into 24-well plates.

Experimental regimen. The temperatures tested were 10,20 and $30^{\circ} \mathrm{C}$, and were controlled using an automatic temperature controlling $\left( \pm 0.5^{\circ} \mathrm{C}\right)$ multiroom incubator. Six salinity groups $(5,10,15,20,25$ and $30 \%$ ) were combined with each temperature. The salinities were adjusted by adding distilled water to ASW and measured daily by a refractometer. The purified prezoosporangia were inoculated into sterile 24well plates and incubated in each experimental condition. The inoculated number of prezoosporangia in each well was 20, and all experimental cultures were performed in triplicate.

The plates were placed in the dark and examined daily under an inverted phase contrast microscope for $15 \mathrm{~d}$. The following 4 criteria were used for evaluation of prezoosporangia development: the first day at which the discharge tube appeared; the day at which free zoospores were found; cumulative sporulation rates $[\mathrm{SR}=$ (number of sporulated zoosporangia/number of all zoosporangia) $\times 100$ ] at Day 15 ; and cumulative release rates of zoospores [ZR $=$ (number of zoosporangia with released zoospores/number of all zoosporangia) $\times 100$ ] at Day 15 .

Statistics. Differences in SR and ZR between prezoosporangia collected in winter and in summer were examined at each temperature and salinity using unpaired Student's $t$-test, and $\mathrm{p}<0.05$ was considered statistically significant.

\section{RESULTS}

The times for appearance of the discharge tube in prezoosporangia, collected in both winter and summer, were shortened in proportion to the increase in temperature and salinity (Table 1). However, no prezoosporangia sampled in summer formed discharge tubes at any salinities when they were maintained at $10^{\circ} \mathrm{C}$.

The times for appearance of free zoospores were also negatively correlated with temperature and salinity in prezoosporangia sampled in both winter and summer (Table 2). However, no free zoospores were observed earlier than $15 \mathrm{~d}$ from prezoosporangia that were sam-

Table 1. First appearance (in d) of discharge tubes of Perkinsus sp. prezoosporangia isolated from Manila clams collected in winter and summer. -: not observed in the $15 \mathrm{~d}$ test period

\begin{tabular}{|c|c|c|c|c|c|c|}
\hline \multirow{3}{*}{$\begin{array}{l}\text { Salinity } \\
(\%)\end{array}$} & \multicolumn{6}{|c|}{ Temperature $\left({ }^{\circ} \mathrm{C}\right)$} \\
\hline & \multicolumn{3}{|c|}{ Winter sample } & \multicolumn{3}{|c|}{ Summer sample } \\
\hline & 10 & 20 & 30 & 10 & 20 & 30 \\
\hline 5 & $8-9$ & $5-6$ & $4-5$ & - & $5-6$ & $2-3$ \\
\hline 10 & $8-9$ & $5-6$ & $1-2$ & - & $4-5$ & $2-3$ \\
\hline 15 & $8-9$ & $4-5$ & $1-2$ & - & $4-5$ & $1-2$ \\
\hline 20 & $7-8$ & $3-4$ & $1-2$ & - & $4-5$ & $1-2$ \\
\hline 25 & $7-8$ & $3-4$ & $1-2$ & - & $4-5$ & $1-2$ \\
\hline 30 & $7-8$ & $3-4$ & $1-2$ & - & $4-5$ & $1-2$ \\
\hline
\end{tabular}

Table 2. First appearance (in d) of free zoospores from Perkinsus sp. prezoosporangia isolated from Manila clams collected in winter and summer. -: not observed in the $15 \mathrm{~d}$ test period

\begin{tabular}{|lrcccccc|}
\hline \multirow{2}{*}{$\begin{array}{l}\text { Salinity } \\
(\%)\end{array}$} & \multicolumn{8}{c|}{ Temperature $\left({ }^{\circ} \mathrm{C}\right)$} \\
& 10 & 20 & 30 & 10 & 20 & 30 \\
\hline 5 & $12-13$ & $9-10$ & $10-11$ & - & - & - \\
10 & $12-13$ & $8-9$ & $6-7$ & - & - & - \\
15 & $12-13$ & $7-8$ & $1-2$ & - & $9-10$ & $4-5$ \\
20 & $11-12$ & $6-7$ & $1-2$ & - & $6-7$ & $3-4$ \\
25 & $9-10$ & $5-6$ & $1-2$ & - & $5-6$ & $2-3$ \\
30 & $9-10$ & $5-6$ & $1-2$ & - & $5-6$ & $2-3$ \\
& & & & & & & \\
\hline
\end{tabular}


Table 3. Cumulative sporulation rates $\left(\mathrm{SR}_{i} \%\right)$ of Perkinsus sp. prezoosporangia exposed to various temperatures and salinities during the $15 \mathrm{~d}$ test period. Values are mean \pm standard deviation. ${ }^{*} \mathrm{p}<0.05{ }_{i}{ }^{* *} \mathrm{p}<0.01$, winter versus summer samples in the same conditions

\begin{tabular}{|lrrrrrr|}
\hline \multirow{2}{*}{$\begin{array}{l}\text { Salinity } \\
(\%)\end{array}$} & \multicolumn{7}{c}{ Temperature $\left({ }^{\circ} \mathrm{C}\right)$} \\
& 10 & 20 & 30 & 10 & 20 & 30 \\
\hline 5 & $8.3 \pm 2.2^{*}$ & $18.3 \pm 2.2$ & $36.7 \pm 5.6^{* *}$ & 0 & $10.0 \pm 3.3$ & $8.3 \pm 2.2$ \\
10 & $10.0 \pm 3.3^{*}$ & $86.7 \pm 8.9$ & $100.0 \pm 0^{* *}$ & 0 & $81.7 \pm 2.2$ & $71.7 \pm 4.4$ \\
15 & $15.0 \pm 6.7^{*}$ & $96.7 \pm 4.4$ & $100.0 \pm 0$ & 0 & $96.7 \pm 4.4$ & $95.0 \pm 3.3$ \\
20 & $28.3 \pm 2.2^{* *}$ & $100.0 \pm 0$ & $100.0 \pm 0$ & 0 & $91.7 \pm 7.8$ & $100.0 \pm 0$ \\
25 & $33.3 \pm 4.4^{* *}$ & $100.0 \pm 0$ & $100.0 \pm 0$ & 0 & $96.7 \pm 4.4$ & $100.0 \pm 0$ \\
30 & $43.3 \pm 7.8^{*}$ & $100.0 \pm 0$ & $100.0 \pm 0$ & 0 & $96.7 \pm 4.4$ & $100.0 \pm 0$ \\
& & & & & & \\
\hline
\end{tabular}

Table 4. Release rates of free zoospores (ZR; \%) of Perkinsus sp. prezoosporangia exposed to various temperatures and salinities. Values are mean \pm standard deviation. ${ }^{*} p<0.05 ;{ }^{* *} p<0.01$, winter versus summer samples in the same conditions

\begin{tabular}{|lcccccc|}
\hline \multirow{2}{*}{$\begin{array}{l}\text { Salinity } \\
(\%)\end{array}$} & \multicolumn{5}{c}{ Temperature $\left({ }^{\circ} \mathrm{C}\right)$} \\
& 10 & 20 & 30 & 10 & 20 & 30 \\
\hline 5 & $8.3 \pm 2.2$ & $11.7 \pm 2.2^{*}$ & $15.0 \pm 3.3^{* *}$ & 0 & 0 & 0 \\
10 & $6.7 \pm 2.2$ & $41.7 \pm 8.9^{*}$ & $65.0 \pm 6.7^{* *}$ & 0 & 0 & 0 \\
15 & $8.3 \pm 2.2^{* *}$ & $60.0 \pm 3.3$ & $86.7 \pm 2.2^{*}$ & 0 & $36.7 \pm 14.4$ & $53.3 \pm 1.1$ \\
20 & $18.3 \pm 2.2^{* *}$ & $71.7 \pm 8.9$ & $76.7 \pm 5.6$ & 0 & $60.0 \pm 10.0$ & $81.7 \pm 2.2$ \\
25 & $13.3 \pm 7.8^{* *}$ & $71.7 \pm 4.4$ & $86.7 \pm 2.2$ & 0 & $76.7 \pm 7.8$ & $91.7 \pm 7.8$ \\
30 & $13.3 \pm 3.8$ & $73.0 \pm 4.4$ & $88.3 \pm 7.8$ & 0 & $86.7 \pm 11.1$ & $93.3 \pm 4.4$ \\
& & & & & & \\
\hline
\end{tabular}

and no sporulation was observed at temperatures below $18^{\circ} \mathrm{C}$ (Perkins 1966, Chu \& Greene 1989). According to the results of Auzoux-Bordenave et al. (1995), prezoosporangia of $P$. atlanticus sporulated only at 24 and $28^{\circ} \mathrm{C}$; sporulation did not occur at 7 and $15^{\circ} \mathrm{C}$ although the viability of prezoosporangia was not affected. In the present study, however, Perkinsus sp. prezoosporangia isolated in the winter sporulated and released motile zoospores at $10^{\circ} \mathrm{C}$, although the rates were significantly lower than those at 20 and $30^{\circ} \mathrm{C}$. In contrast, no prezoosporangia collected during the summer sporulated at $10^{\circ} \mathrm{C}$. The difference in developmental ability at low temperatures between winter and summer samples in this study suggests that prezoosporangia of Perkinsus sp. sampled in winter probably have an innate adaptation or tolerance to low temperatures and, therefore, can trigger their zoosporulation more readily at low temperatures than those sampled in summer. Since the water temperature of the present sampling area in winter ranges from 8 to $12^{\circ} \mathrm{C}$, zoosporulation of Perkinsus sp. might be possible even in winter.

pled in summer and incubated either at $10^{\circ} \mathrm{C}$ or at 20 and $30^{\circ} \mathrm{C}$ combined with 5 and $10 \%$.

Both SR and ZR were positively related to temperature and salinity (Tables $3 \& 4$ ). At $10^{\circ} \mathrm{C}$, development of prezoosporangia was somewhat inhibited in the winter sample and completely inhibited in the summer sample. Prezoosporangia sampled in winter and incubated at 5 and $10 \%$ at $30^{\circ} \mathrm{C}$ showed significantly higher SR than those sampled in summer and incubated in the same conditions. ZR in the winter sample were significantly higher than those in the summer sample at the lower salinities.

\section{DISCUSSION}

The present results clearly showed that temperature had a significant effect on in vitro zoosporulation of Perkinsus sp. prezoosporangia, and the developmental rates increased with increasing temperature. Temperature-dependent in vitro development of prezoosporangia has been observed, also, in other Perkinsus species. It was reported that optimum temperature for sporulation of $P$. marinus prezoosporangia was $28^{\circ} \mathrm{C}$,
In the present study, low salinities ( $\leq 10 \%$ ) did have a strong negative effect on the development of Perkinsus nus prezoosporangia has also been reported to be significantly affected by salinity (Perkins 1966, Chu \& Greene 1989). Salinity lower than 6\% inhibited the sporulation of $P$. marinus prezoosporangia (Chu \& Greene 1989). Salinities ranging between 25 and 35\% promoted the best development of $P$. atlanticus prezoosporangia, but no sporulation occurred within $5 \mathrm{~d}$ at $5 \%$ (Auzoux-Bordenave et al. 1995). A small number of Perkinsus sp. prezoosporangia sampled in summer in this study did sporulate at 5\%, but further development including formation and release of zoospores was not observed. However, prezoosporangia sampled in winter and incubated at $5 \%$ released motile zoospores, though the rates were considerably lower than those at higher salinities. The reasons for this difference are not known, but prezoosporangia sampled in winter seemed to have more tolerance to low salinity and low temperature than those sampled in summer.

Although the biological significance of zoosporulation in Perkinsus species is not clear because zoosporangia are rarely found in host tissue, zoospores sp. prezoosporangia. In vitro development of $P$. mari- 
must have some function or their production would not have evolved (Burreson \& Ragone Calvo 1996). Auzoux-Bordenave et al. (1995) proposed that the prezoosporangial stage of $P$. atlanticus obtained in artificial conditions in FTM happens in natural conditions when the host dies, due to anaerobic conditions created inside tissues. When released in seawater, $P$. atlanticus sporangia sporulate quickly and in 2 to $3 \mathrm{~d}$ produced hundreds of biflagellated zoospores, which are an infective and dispersive stage of the parasite. In the present study, the role of zoospores in the early infection of Perkinsus sp. was not investigated. However, the high tolerance of prezoosporangia collected in winter to low temperatures might explain the high prevalence $(100 \%)$ and infection intensity $(2.87$ according to Mackin's scale) of Perkinsus sp. in Manila clams collected from a southern bay of Korea in winter (Park et al. 1999).

In conclusion, temperature and salinity have a significant effect on the in vitro development of Perkinsus sp. prezoosporangia isolated from Manila clams, and further research is needed to elucidate why prezoosporangia collected during different seasons showed different developmental responses to low temperatures and low salinities.

\section{LITERATURE CITED}

Andrews JD (1955) Notes on fungus parasites of bivalve mollusks in Chesapeake Bay. Proc Natl Shellfish Assoc 45: 157-163

Andrews JD, Hewatt WG (1957) Oyster mortality studies in Virginia. II. The fungus disease caused by Dermocystidium marinum in oysters in Chesapeake Bay. Ecol Monogr 27:1-26

Auzoux-Bordenave S, Vigario AM, Ruano F, Domart-Coulon I, Doumenc D (1995) In vitro sporulation of the clam pathogen Perkinsus atlanticus (Apicomplexa, Perkinsea) under various environmental conditions. J Shellfish Res 14:469-475

Azevedo C (1989) Fine structure of Perkinsus atlanticus n. sp. (Apicomplexa, Perkinsea) parasite of the clam Ruditapes decussatus from Portugal. J Parasitol 75:627-635

Blackbourn J, Bower SM, Meyer GR (1998) Perkinsus qugwadi sp. nov. (incertae sedis), a pathogenic protozoan parasite of Japanese scallops, Patinopecten yessoensis, cultured in British Columbia, Canada. Can J Zool 76: 942-953

Burreson EM, Ragone Calvo LM (1996) Epizootiology of Perkinsus marinus disease of oysters in Cheaspeake Bay, with emphasis on data since 1985. J Shellfish Res 15:17-34

Burreson EM, Ragone Calvo LM, La Peyre JF, Counts F, Paynter KT Jr (1994) Acute osmotic tolerance of cultured cells of the oyster pathogen Perkinsus marinus (Apicomplexa: Perkinsida). Comp Biochem Physiol 109A:575-582

Choi KS, Park KI (1997) Report on the occurrence of Perkinsus sp. in the Manila clams, Ruditapes philippinarum in Korea. J Aquac 10:227-237

Choi DL, Kwon JN, Park SW (1998) Infection and rapid detec-

Editorial responsibility: Albert Sparks,

Seattle, Washington, USA tion of Perkinsus sp. in cultured babyneck clam, Ruditapes philippinarum from western coast of Korea. J Fish Pathol 11:69-76 (in Korean)

Chu FLE, Greene KH (1989) Effect of temperature and salinity on in vitro culture of the oyster pathogen, Perkinsus marinus (Apicomplexa: Perkinsea). J Invertebr Pathol 53: $260-268$

Chu FLE, La Peyre JF (1993) Perkinsus marinus susceptibility and defense-related activities in eastern oysters Crassostrea virginica: temperature effects. Dis Aquat Org 16: 223-234

Chu FLE, La Peyre JF, Burreson CS (1993) Perkinsus marinus infection and potential defense-related activities in eastern oysters, Crassostrea virginica, salinity effects. J Invertebr Pathol 62:226-232

Coss CA, Robledo JA, Ruiz GM, Vasta GR (2001) Description of Perkinsus andrewsi n. sp. isolated from the Baltic clam (Macoma balthica) by characterization of the ribosomal RNA locus, and development of a species-specific PCRbased diagnostic assay. J Eukaryot Microbiol 48:52-61

Crosby MP, Roberts CF (1990) Seasonal infection intensity cycle of the parasite Perkinsus marinus (and an absence of Haplosporidium spp.) in oysters from a South Carolina salt marsh. Dis Aquat Org 9:149-155

da Ros L, Canzonier WJ (1985) Perkinsus, a protistan threat to bivalve culture in the Mediterranean basin. Bull Eur Assoc Fish Pathol 5:23-25

Goggin CL, Lester RJG (1987) Occurrence of Perkinsus species (Protozoa, Apicomplexa) in bivalves from the Great Barrier Reef. Dis Aquat Org 3:113-117

Goggin CL, Sewell KB, Lester RJG (1990) Tolerance of Perkinsus spp. (Protozoa, Apicomplexa) to temperature, chlorine and salinity. J Shellfish Res 9:145-148

Lester RJG, Davis GHG (1981) A new Perkinsus species (Apicomplexa, Perkinsea) from the abalone Haliotis ruber. J Invertebr Pathol 37:181-187

Mackin JG, Owen HM, Collier A (1950) Preliminary note on the occurrence of a new protistan parasite, Dermocystidium marinum n. sp., in Crassostrea virginica (Gmelin). Science 111:328-329

McLaughlin SM, Tall BD, Shaheen A, Elsayed EE, Faisal M (2000) Zoosporulation of a new Perkinsus species isolated from the gills of the softshell clam Mya arenaria. Parsite 7: $115-122$

Park KI, Choi KS, Choi JW (1999) Epizootiology of Perkinsus sp. found in the Manila clam, Ruditapes philippinarum in Komsoe Bay, Korea. J Korean Fish Soc 32:303-309 (in Korean)

Perkins FO (1966) Life history studies of Dermocystidium marinum, an oyster pathogen. PhD dissertation, Florida State University, Tallahassee

Perkins FO (1996) The structure of Perkinsus marinus (Mackin, Owen and Collier, 1950) Levine, 1978 with comments on taxonomy and phylogeny of Perkinsus spp. J Shellfish Res 15:67-87

Ragone Calvo LM, Burreson EM (1994) Characterization of overwintering infections of Perkinsus marinus (Apicomplexa) in Chesapeake Bay oysters. J Shellfish Res 13: $123-130$

Ray SM (1954) Studies on the occurrence of Dermocystidium marinum in young oysters. Proc Natl Shellfish Assoc 44: $80-92$

Siddall ME, Reece KS, Graves JE, Burreson EM (1997) 'Total evidence' refutes the inclusion of Perkinsus species in the phylum Apicomplexa. Parasitology 115:165-176

Submitted: January 25, 2001; Accepted: September 13, 2001 Proofs received from author(s): December 10, 2001 